\title{
Thio-TEPA の慢性毒性につレて
}

\section{まえおき}

ドイツのへキスト社研究陣によつて始めて合成がなさ れ(1), アメリカのBUCKLEY et $a l^{2)}$ (1951) によつて抗 腫盼性の確認された燐酸系 ethyleneimine 化合物は更 に安定性の高い thio-燐酸采化合物に発展するに及ん で，臨床的にも注目されるようになつてきた。ここに取 扱う Thio-TEPA は TESPA またはSTEPA などと も略称され， N, N', N"-triethylene-thio-phosphoramide (困 1) の構造をもつ一種のアルキル化郕で, ア<smiles>S=P(N1CC1)(N1CC1)N1CC1</smiles>

(図 1) Thio-TEPA メリカの PERSONEUS et $a l^{3}$ (1952), CROSSLEY et $a l^{4}$ (1953) がその抗腫璂作 用を報告して以来, 臨床的 効果についても, SHAY et $a l^{5)}$ (1953), BATEMAN et $a l^{6)}$ (1955) を始めと.して， 多数の発表がある。わが国では実験的に山本, 山岡 $5^{7,8)}$ (1953-54), 石館, 桜井ら9) (1955) により先鞭がつけら れ，臨床的にも検討が進められている物質である。

処でこれらのアルキル化剂としての抗腫湟性物質には 放射線類似作用物質の名があるように多少の差はあつて 放射線作用に類似の性質があつて, 従つて放射線治療 に伴 5 副作用に類似の副作用が警戒される。しかしイギ リスに打ける独特の研究によれば，同じ放射線類似作用 物質でも Busulfan (Burroughs Wellcome \& Co 市販品 “Myleran”) は特に骨髄性白血病に期待され るよ5に白血球系統に著しい作用を示し, 逆に $\mathrm{N}, \mathrm{N}^{\prime}-$ di (2-chloroethyl)-p-aminophenylbutylic acid (CB 1348）は骨髄組織への作用がむしろ弱くリンパ組織への 選択性に期待されるといつた具合で，物質によつてその 親和性に差異のあることが知られてきている。すなわち 同じ放射線類似作用物質でもその作用に特徽のあること が問題になる。(参照一山本ら ${ }^{10)}$ (1956)) Thio-TEPA にもそのような特徴があるかどうかを明らかにして沶く ことは，比較的長期間に渉つて使用されることの多いこ の種の薬剤の副作用を予知する上にも，また併用療法へ の機運が高まりつつある現状より見て毒性の相乗作用を 避ける薬凧の組合せを考慮する上にも重要な間題になる と思われる。 $\begin{array}{lclll}\text { 山 本 } & \text { 正 竹内美恵子 } \\ \text { 草 野 信 男 織 田 昭 }\end{array}$ 東大伝染病 研 究 所 日本大学医学部細菌学教室

一方慢性毒性の有無を検查する動物実験法としての基 蕉化はこの種の薬凧の臨床応用の前段階として今後益々 重要となるに違いないが，な打基礎的条件の確立に行悩 んでいる向きが多く，その間題のありかを窅知しておく ことは将来とも重要なことと思われる。

私共が Thio-TEPA のマウスに拈ける慢性毒性を㭘 查するために企図した心構えは以上のようなものといえ よ。

\section{実験材料ならびに実験方法}

1） マウス SM (CLEA):生後 4 週っを使用した。金 網籠におさめた CLEA の飼育用固型飼料と水道水をい れた吸水瓶を常用して大型の金属ヶージに飼育した。し きわらは 1 週 1 回交換。

2）TESPA：住友化学 $\mathrm{KK}$ の試験品。同社研究部に よれば，本品の融点は $54.5^{\circ}-55.5^{\circ} \mathrm{C}$ で，マウス（腹腔 内）の急性毒性值は $\mathrm{LD}_{50} 19.5 \mathrm{mg} / \mathrm{kg}$ である。100mg 入りのゴム密栓瓶にまず $1 \mathrm{ml}$ の生理食塩水を加え, 濁 りのないことを確めてから $10 \mathrm{ml}$ に稀釈する。これを原 液として $-20^{\circ} \mathrm{C}$ の冷涷庫中に保存しつつ用時溶解し所 要濃度に生理食塩水で稀釈した。1週ごとに新しい瓶と 取換え変質製品の使用をさけた。

3）注射ならびに観察方法：1群 10 匹として個々に 体重を測定し，大凡の体重によつて kg あたりの薬威量 より注射量を決定しながら所要量を毎日 1 回 28 日間連 日腹腔内に注射した。 $\mathrm{kg}$ 当り 1 日量 $5 \mathrm{mg}, 1 \mathrm{mg}, 0.2$ $\mathrm{mg}, 0.1 \mathrm{mg}, 0.05 \mathrm{mg}, 0.025 \mathrm{mg}$ を選んだのは人の治療 量 (1〜 10mg/day) を考慮し，また我々のマウス Ehrlich 瘦の治療実験 ${ }^{7,8)}$ から $2.5 \mathrm{mg} / \mathrm{kg} /$ day で腫瘤型に 有効であることと，前記の急性毒性をる考慮にいれ，ま た SUGIURA et $a l^{11)}(1955)$ が担癌マウスに 8,4,2 及 び $1 \mathrm{mg} / \mathrm{kg} /$ day（腹腔内） 7 日間連続投与して，夫々 50 , 1, 0 及び $0 \%$ 死亡率であつたと発表しているのを参考 にした。観察期間中は3〜 日間隔で体重を測定しながら 注射量を加減し，途中で死亡しまたは全注射期間を経過 したマウスは剖検して, 大腿骨を含む各臓器を 5 倍ホル マリン水で固定, 骨は脱灰後他はそのまま型のよ5に切 片となし，ヘマトキシリンエオジン染色標本としてその 変化を追及した。なお剖湌前には鼠蹊部を開き肢動脈を 切断これより採血して白血球数をしらべると共に肉眼的 
ならびに組織学的に追及した。

\section{実験結果ならびに考察}

\section{1）体重增加率と生存に対する影济}

第 1 図に平均体重増加率と生存率をまとめてみた。当 初の平均体重は $15.44 \pm 0.12 \mathrm{~g}$ (55 匹)でかなり揃つた体 重を示していたが， 4 週間の連日注射と飼育によつて薬 放濃度に応じて図のような変動を示したわけである。す

図1マウスの生残率と体重增加度
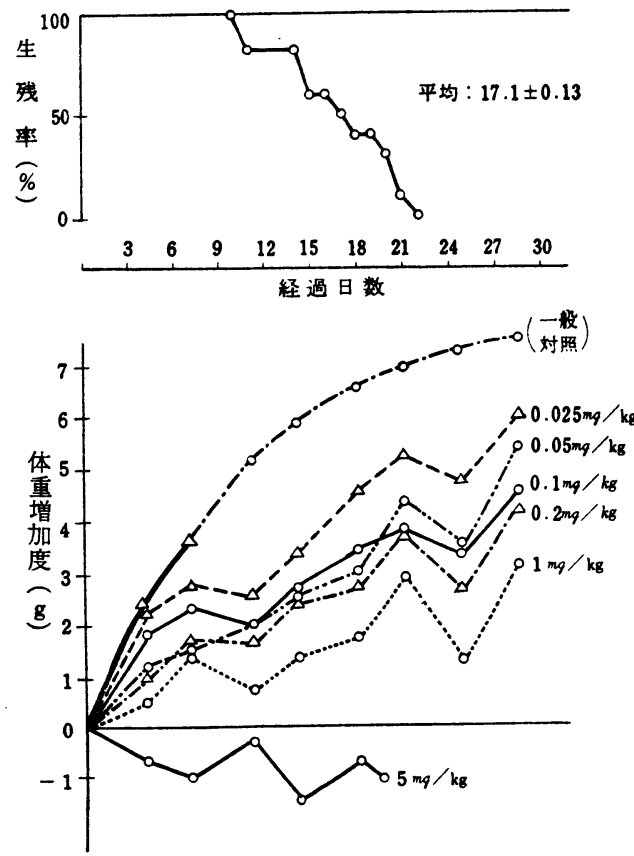

なおち $5 \mathrm{mg} / \mathrm{kg}$ 群では体重は漸减し 22 日までに全部死 亡し, $1 \mathrm{mg} / \mathrm{kg}$ 以下の各群では体重は増加するがそれぞ
いるが，実際この種の長間期観察実験には環境の影響が 意外に大きいので, 恒温恒湿の動物飼育室の如きを用い この種の観察を行らべきことが首肯されるというもので ある。

このように薬凧注射という操作以外に環境の影響やさ らには個体差の影響の加わつている実験結果を統計的に 取扱う場合には，順位による検定法(Rank method)が有 利のように思われる ${ }^{12)}$ 。この検定法は正規母集団の仮定 が不必要で, 分散の均一性を心配しなくてよい利点があ りもちろん精度はやや执ちるが，この種の実験結果の好 理上には簡便で推賞され.5るものの一つであろ5。

表 1 に各群の体重増加度を殆んど毒性の現われていな い $0.025 \mathrm{mg} / \mathrm{kg}$ 群の示すそれに比較してH検定を行つた 結果を示した。 $1 \mathrm{mg} / \mathrm{kg}$ 群のみが $5 \%$ の危険率で有意の

表 1 各注射群の 4 週後の体重增加度成績

\begin{tabular}{|c|c|c|c|c|c|}
\hline & $\mathbf{a}$ & b & c & $d$ & e \\
\hline & $1 \mathrm{mg}$ & $0.2 \mathrm{mg}$ & $0.1 \mathrm{mg}$ & $0.05 \mathrm{mg}$ & $0.025 \mathrm{mg}$ \\
\hline \multirow{10}{*}{ 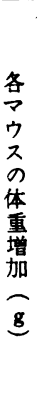 } & 0.7 & 0.7 & 0.3 & 2.4 & 2.2 \\
\hline & 0.9 & 1.6 & 1. 5 & 3. 5 & 3. 2 \\
\hline & 1. 5 & 2. 1 & 2.4 & 3. 5 & 4. 7 \\
\hline & 2. 5 & 2. 5 & 3. 5 & 5. 0 & 5. 9 \\
\hline & 2. 5 & 2. 5 & 3. 7 & 5. 1 & 6.7 \\
\hline & 2. 5 & 3. 0 & 5. 0 & 5. 3 & 7. 2 \\
\hline & 4. 2 & 5. 8 & 6. 3 & 5. 7 & 8. 0 \\
\hline & 4. 8 & 6.4 & 7.7 & 7.8 & 10.4 \\
\hline & 8. 5 & 7.4 & 10.7 & 9. 0 & \\
\hline & & 10.2 & & 9. 1 & \\
\hline 平 & 3.2 & 4. 22 & 4.56 & 5.64 & 6.04 \\
\hline 均 & \pm 0.86 & \pm 1.03 & \pm 1.15 & \pm 0.77 & \pm 1.09 \\
\hline & $\mathbf{a}: \mathbf{e}$ & b : e & $c: \mathbf{e}$ & $\mathrm{d}: \mathrm{e}$ & \\
\hline 検 & $\mathrm{H} \equiv 3.89$ & $\mathrm{H} \equiv 2.50$ & $\mathrm{H} \equiv 0.83$ & $H \equiv 0.51$ & \\
\hline 定 & $\mathrm{P}<0.05$ & $0.10<P<0.25$ & $0.25<P<$ & 0.500 .25 & $3<P<0.50$ \\
\hline
\end{tabular}

れの薬成濃度に応じてある程度づつ体 重増加が抑制されていることが解る。 対照群を途中から別の用途に使用して しまつているので, ここには参考まで に我々の手持のデータより平均体重増 加曲線でそのあとを補つてみたが，そ れは必ずしも妥当でないことがこの平 均体重の振れから解る。本実験は10月 より11月ハかけて行つたものであるが 25日目に全般的に体重の减少を来して いるのは急激に気温の低下したためで あり，表1からも解るように体重増加 度の個体差が意外に著しい。体重曲線 がものをいおない動物の健康状態を示 す簡易なバロメーターと考えられては
表2 $00.25 \mathrm{mg}$ 群と $1 \mathrm{mg}$ 群との体重増加度よりみた比較

\begin{tabular}{|c|c|c|c|c|c|c|c|}
\hline \multicolumn{2}{|c|}{14 日目 } & \multicolumn{2}{|c|}{21 日目 } & \multicolumn{2}{|c|}{25 日目 } & \multicolumn{2}{|c|}{29 日目 } \\
\hline $0.025 \mathrm{mg}$ & $1 \mathrm{mg}$ & $0.025 \mathrm{mg}$ & $1 \mathrm{mg}$ & $0.025 \mathrm{mg}$ & $1 \mathrm{mg}$ & $0.025 \mathrm{mg}$ & $1 \mathrm{mq}$ \\
\hline 各 $\quad 0$ & -1.4 & 1.5 & 0.3 & 1.0 & -1.5 & 2.2 & 0.7 \\
\hline $\begin{array}{ll}\nabla & 0.3\end{array}$ & -0.5 & 3.0 & 0.6 & 2.4 & -1.0 & 3.2 & 0.9 \\
\hline ウ $\quad 2.7$ & 0.2 & 4.0 & 1.9 & 3.2 & 0 & 4.7 & 1.5 \\
\hline $\begin{array}{ll}\pi & 2.8\end{array}$ & 0.8 & 4.3 & 2.2 & 4.4 & 0.2 & 5.9 & 2.5 \\
\hline $\begin{array}{l}\text { の } \\
\text { 体 }\end{array}$ & 1.3 & 5.5 & 2.3 & 4.7 & 0.6 & 6.7 & 2.5 \\
\hline 重 5.5 & 1.7 & 6.9 & 3.2 & 6.5 & 1.2 & 7.2 & 2.5 \\
\hline 增 5.6 & 1.7 & 7.6 & 3.4 & 7.1 & 2.0 & 8.0 & 4.2 \\
\hline 加 6.0 & 2.0 & 9.0 & 4.0 & 8.4 & 2.6 & 10.4 & 4.8 \\
\hline (g) & 6.3 & & 7.9 & & 7.2 & & 8.5 \\
\hline 平 3.25 & 1.34 & 5.22 & 2.86 & 4.71 & 1.25 & 6.04 & 3.12 \\
\hline 均 \pm 0.87 & \pm 0.75 & \pm 0.94 & \pm 0.74 & \pm 0.99 & \pm 0.60 & \pm 1.09 & \pm 0.86 \\
\hline $\begin{array}{lr}\text { 検 } & \text { H } \\
\text { 定 } & 0.10< \\
\end{array}$ & $\begin{array}{l}2.52 \\
<0.25\end{array}$ & $\begin{array}{r}H \equiv 3 \\
0.05<P \\
\end{array}$ & $\begin{array}{l}3.33 \\
<0.10\end{array}$ & $\begin{array}{r}\mathbf{H} \equiv \\
\mathbf{P}<0\end{array}$ & $\begin{array}{l}5.44 \\
0.025 \\
\end{array}$ & $\begin{array}{l}\mathbf{H} \equiv 3 \\
\mathbf{P}<0\end{array}$ & $\begin{array}{l}3.89 \\
.05\end{array}$ \\
\hline
\end{tabular}


差を示していることは, この $1 \mathrm{mg} / \mathrm{kg}$ 群のみが白血球 減少症を示し組織学的にも骨髄の变化を軽度に認めてい る点で暗合している。また $1 \mathrm{mg} / \mathrm{kg}$ 群では一体何時ご ろからこの毒性があらわれてきているかを体重増加度か らこの検定で推定するために表 2 のような計算を行つ た。 3 週間ではまだはつきりしないがそれ以後で出現し ているよ5に思われる。25日目で寒冷の影響が $1 \mathrm{mg} / \mathrm{kg}$ の㵔しいことは興味あることであろう。

\section{2) 剖検荗器よりの検索}

Thio-TEPA $5 \mathrm{mg} / \mathrm{kg}$ 投与群で死亡前に下麻症状を示 すものもあつたが，そのまま望䶃して死亡するものが多 かつた。死亡マウスはその都度剖榆し, 臓器をホルマリ ン固定したが，肉眼的に脾蔵の縮少が目立ち，大腿骨骨 髄ときにリンパ節にも出血性傾向が認められた。

4 週間連日注射した $1 \mathrm{mg} / \mathrm{kg}$ 以下 Thio-TEPA の投 与群は 29 日目に肢動脈を切断して放血させ, その一部 で白血球数を計測すると共に剖検し, 脾の重量を計測し て各臓器を固定した。白血球計算値と脾重量の結果を表 3 にまとめた。白血球数よりみると, $1 \mathrm{mg} / \mathrm{kg}$ 群には $0.05 \mathrm{mg} / \mathrm{kg}$ 群との間に $0.5 \%$ 以下の危険率で有意の差 があり, この量の連続注射てよつて白血球减少症が起っ ていることが認められるが, 脾の縮少は $1 \mathrm{mg} / \mathrm{kg}$ 投与群 には起つていない。それらは病理組織学的にも確められ た。 $0.5 \mathrm{mg} / \mathrm{kg}$ 以下の投与群にはこの範图の投与期間で

\begin{tabular}{|c|c|c|c|c|c|c|}
\hline 表3 & 各注 & 树に & $51 T 2 月$ & 里重 & :日並 \pm & \\
\hline $\begin{array}{l}5 \mathrm{mg} \\
\text { (a) }\end{array}$ & $\begin{array}{l}1 \mathrm{mg} \\
(\mathrm{b})\end{array}$ & $\begin{array}{r}0.2 \mathrm{mg} \\
(\mathrm{c})\end{array}$ & $\begin{array}{l}0.1 \mathrm{mg} \\
(\mathrm{d})\end{array}$ & $\begin{array}{c}0.05 \mathrm{mg} \\
(\mathrm{e})\end{array}$ & $\begin{array}{c}0.025 \mathrm{mg} \\
\text { (f) }\end{array}$ & \\
\hline 25 & 162 & 220 & 281 & 202 & 178 & \\
\hline 20 & 138 & 160 & 145 & 173 & 120 & \\
\hline 14 & 123 & 122 & 138 & 165 & 106 & M \\
\hline & 116 & 120 & 92 & 151 & 115 & I \\
\hline & 116 & 114 & 68 & 84 & 89 & L \\
\hline & 92 & 99 & 70 & & 83 & Z \\
\hline & 88 & & & & 63 & $m g$ \\
\hline & 62 & & & & 58 & \\
\hline & 56 & & & & & \\
\hline & b : c H & $\equiv 1.24$ & & & & \\
\hline & $0.25<p$ & $<0.50$ & & & & \\
\hline 1400 & 6970 & 12000 & 11850 & 10900 & 9600 & \\
\hline 900 & 4450 & 11375 & 10600 & 9880 & 8600 & \\
\hline 900 & 3660 & 11150 & 10500 & 7100 & 8240 & \\
\hline & 3650 & 10275 & 8950 & 6720 & 7750 & \\
\hline & 3500 & 9630 & 8950 & 6700 & 6800 & \\
\hline & 3050 & 8950 & $\therefore$ & & 6020 & s \\
\hline & 2880 & & & & 5120 & $\mathrm{~S}$ \\
\hline & 2800 & & & & 5000 & \\
\hline & 2800 & & & & & \\
\hline 1066 & 3862 & 10563 & 10170 & 8260 & 7141 & \\
\hline & \pm 462 & \pm 510 & \pm 617 & \pm 992 & \pm 636 & \\
\hline & $\begin{array}{c}b: c \\
H \equiv 9.75\end{array}$ & $\begin{array}{c}c: \\
H \equiv\end{array}$ & $\begin{array}{l}d \\
3.79\end{array}$ & $\begin{array}{c}\mathrm{d}: \mathrm{e} \\
\mathrm{H} \equiv 1.5\end{array}$ & & \\
\hline & $P<0.00$ & $\mathrm{P}<$ & 0.1 & $\mathrm{P}<0.2$ & & \\
\hline
\end{tabular}

は認むべき毒性が認められず, 病理組織学的にも薬物に よる変化を認め得なかつた。

\section{3）継時的観察}

$5 \mathrm{mg} / \mathrm{kg}$ の Thio-TEPA 投与により特長ある病変を 伴ってマウスが致死することが知れたので, その病変の 推移を継特的に追及することによつてその間の消息をは つきりさせようと試みた。白血球数は既に 4 回注射後の 4 日目に 1000 台に低下していてかなり急速な減少であ るが, 病理組織学的にはな挆骨髄の造血機能は残存して いる。むしろ 7 回注射後の 7 日目に造血機能が著明に侵 され, いわゆる形成不全の状態を呈すると共に出血性素 因が出現する。またその頃より感染症が加わる像も認め られる。

脾重量の推移を図 2 にまとめてみたが，10日以後に著 明な縮少を認めらるが，これに平行して病理組織学的に も脾の著しい萎縮像を認め, その像は濾胞を比較的よく 残し細状織が強く犯される点でX線照射時の像と異る。 興味ある所見と思 われる。

睪丸内の造精機 能は低下はするが 相当に保持され ていて, 造血機能 抑制に比して強く はない。

他の肝, 腎, 肺, 心臓その他には薬

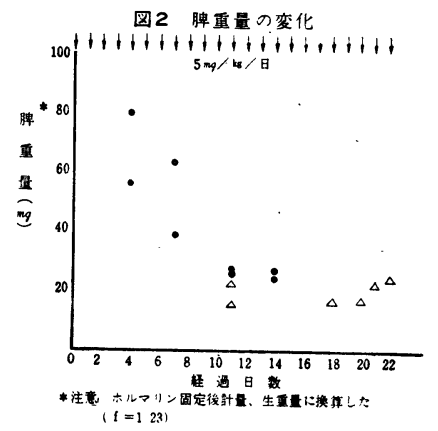
物による病変はまずこれを認めず, 肝, 肺などに感染に よるものと思われる脂肪変性その他を時に認めた程度で ある。リンパ腺の所見は感染像が加つたものが多いた め, 薬物の影響を確めにくかつたのでここには保留した い。

以上の所見より要約されることは Thio-TEPA は $1 \mathrm{mg} / \mathrm{kg} /$ day 連日 4 週間で白血球減少症を来たすよ5 にむしろ白血球系細胞への親和性が強く, $5 \mathrm{mg} / \mathrm{kg} / \mathrm{day}$ で致死毒性を示すがこの時脾萎縮を来たすのであつて, リンパ系細胞への影響は比較的弱いとみることができよ 5 。

\section{結論}

Thio-TEPA (Triethylene-thio-phosphoramide) の $5 \mathrm{mg} \sim 0.025 \mathrm{mg} / \mathrm{kg} /$ day $の$ 連日投与 4 週間におよぶ SM マウスの慢性毒性を検討し次のことを知つた。

1） $5 \mathrm{mg} / \mathrm{kg} /$ day の連日投与は脾の著しい縮少と骨髄 造血機能の破壊を伴つてマウスを平均 17.1士0.13日で 致死させる。

2） $1 \mathrm{mg} / \mathrm{kg} /$ day の連日投与でほ体重培加が抑制され 
4 週後に白血球減少症をひきおこす。

3) $0.5 \mathrm{mg} / \mathrm{kg} /$ day 以下の 4 週間連日投与では認むべ き毒性が認められない。

4) Thio-TEPA はリンパ禾細胞よりは白血球系細胞 に親和性が強い。

以上の所見は病理組織学的検索の裏ずけにたつて数計 学的にも㭘討された。

なお本実験の逐行に当つては畏友山岡静三郎薬博の助 言と芳情を辱くした。誌して謝意を表する。(山本)

\section{引用交献}

1) Bestian, H. (1950): Über einige Reaktionen des Äthylen-imins. Ann. Chemie, 566, 210-244.

2) BuCKLEY, S. M., C. C. STOCK, R. P. PARKER, M. L. Crossley, E. KuH, \&. D. R. SeEGER (1951): Inhibition studies of some phosphoramides against sarcoma 180. Proc. Soc. Exper. Biol. Med., 78, 299-305.

3) Peroneus, G., S. L. Halliday, D.MckenzIE, \& J. H. WILliams (1952): Effect of a series of ethylenimine derivatives against metastasizing mammary adenocarcinoma of the rat. Proc. Soc. Exper. Biol. Med., 81, 614616.

4) Crossley, M. L., J. B. Allison, R. P. PARKER, E. KUH, \& D. R. SEEGER (1953): IIIChemotherapy of tumors in rats with certain ethylenephosphoramides. Proc. Soc. Exper. Bi-

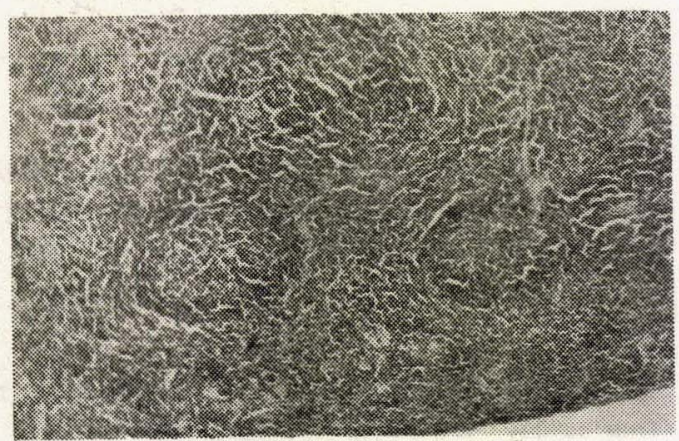

$1 \mathrm{mg} / \mathrm{kg} /$ day 28 日注射後の脾臓 まず正常

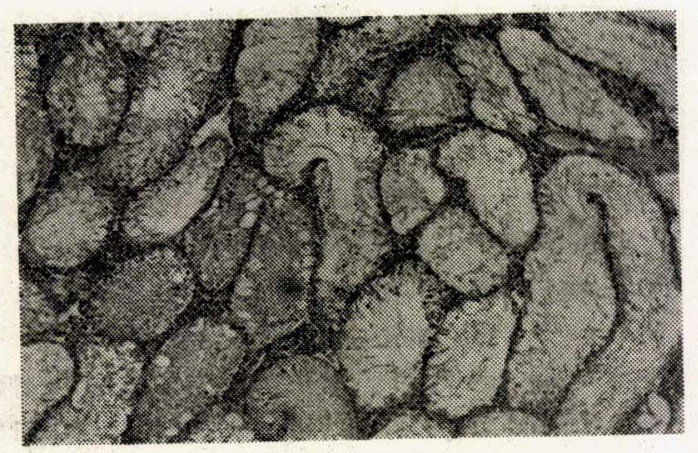

$1 \mathrm{mg} / \mathrm{kg} /$ day 28 日注射後の粹丸一 部の造精機能がおかされている。 ol. Med., 83, 438-447.

5) Shay, H., C. Zarafonetis, N. Smith, I. Woldow, \& D. C. H. SUN (1953): Treatment of leukemia with Triethylene Thiophoramide (Thio-TEPA). Arch. Intern. Med., 92, 628 -645 .

6) Bateman, J. C. (1955): Chemotherapy of solid tumors with Triethylene Thiophosphoramide. New England $J$. of Med., 252, 879-887.

7) 山本正, 山岡静三郎, 古明地隆江 (1953): 抗腫瘍 剂の研究, (第 5 報) 憐酸系エチレンイミ，化合物に ついて。昭和 28 年 11 月 26 日, 伝研予研集談会発表。 8) 山岡静三郎, 古明地隆江, 山本正 (1954): 悪性腫 瘍の実験的化学療法 (第 $1,2,3$ 報)。第 7 回日本薬 学大会発表, 昭和 29 年 4 月 4 日, 京都。

9) 石館守三, 桜井欽夫, 吉田富三, 佐藤博, 今村博 (1955)：吉田内腫を用いた悪性腫瘍の化学療法に関 する実験的研究 (第 $8,9,10$ 報)。第 14 回日本癌学 会総会発表, 昭和 30 年 4 月 4 日, 京都 (癌, 46. 469 -482)。

10) 山本正, 山岡静三郎 (1956): 癌の化学療法剤。中 原, 吉田監修癌研究の進歩, $571 \cdot 619$ 。(医学書院)。

11) SugrurA, K. \& C. C. STock (1955): Stud-i es in a tumor spectrum. III. The effect of phosphoramides on the growth of a variety of mouse and rat tumors. Cancer Res. 15, 38-51.

12）石崎有信 (1953): 順位による簡易な統計学的検定 法。日本医事新報, 1522 号 40-41, 昭和 28 年 7 月 18 日。

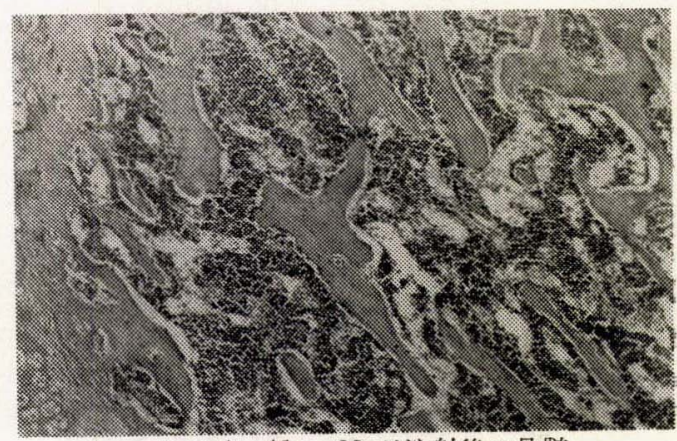

$1 \mathrm{mg} / \mathrm{kg} /$ day 28 日注射後の骨髄 やや造血機能がおかされている。

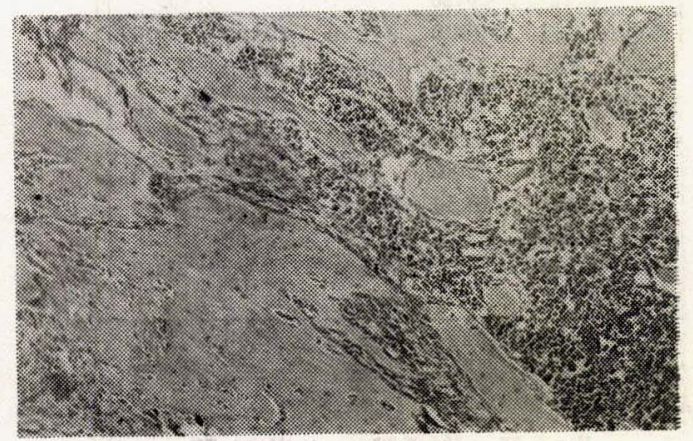

$5 \mathrm{mg} / \mathrm{kg} /$ day 4 日注射後屠殺の骨髄 やや造血機能がおかされている。 


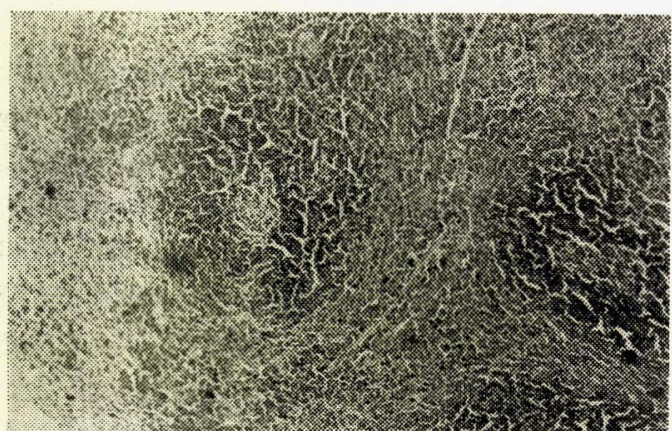

$5 \mathrm{mg} / \mathrm{kg} /$ day 4 日間注射後屠殺の脾臓 まず正常

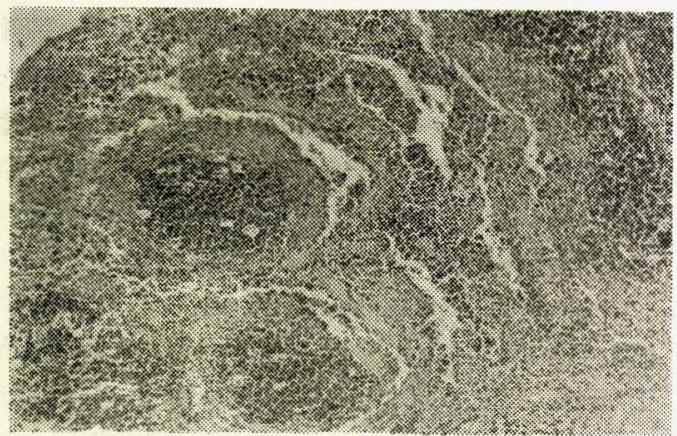

$5 \mathrm{mg} / \mathrm{kg} /$ day 10 日間注射後死亡の脾臟 滤胞索残して萎縮著明

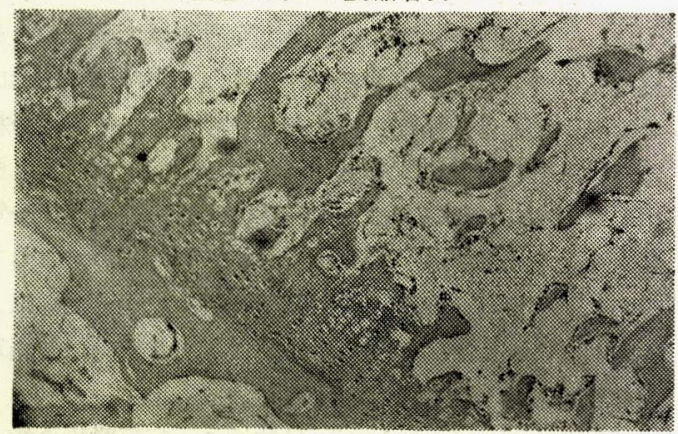

$5 \mathrm{mg} / \mathrm{kg} /$ day 21 日間注射後屠殺の骨䯣 造血機能消失

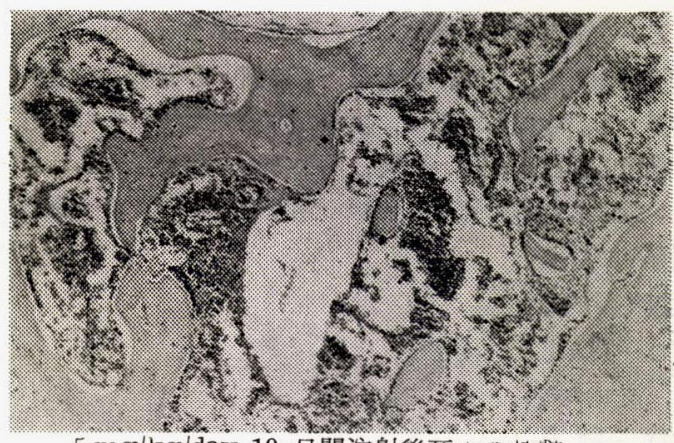

$5 \mathrm{mg} / \mathrm{kg} / \mathrm{day} 10$ 日間注射後死亡学能道 造血機能殆えぞ消失し出血性となる。

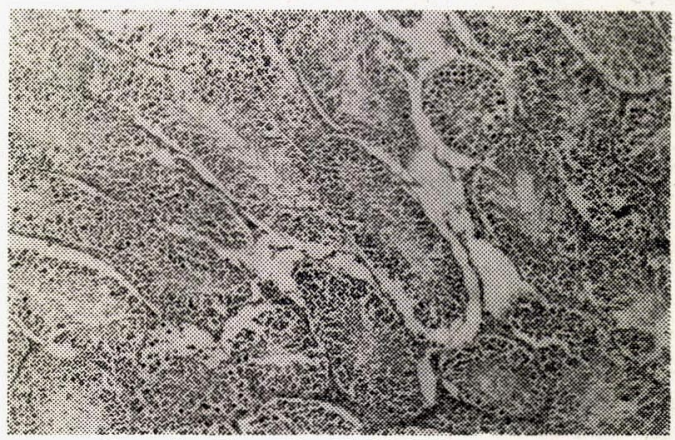

$5 \mathrm{mg} / \mathrm{kg} /$ day 10 日間注射後死亡の軒丸 あまりおかされていない。

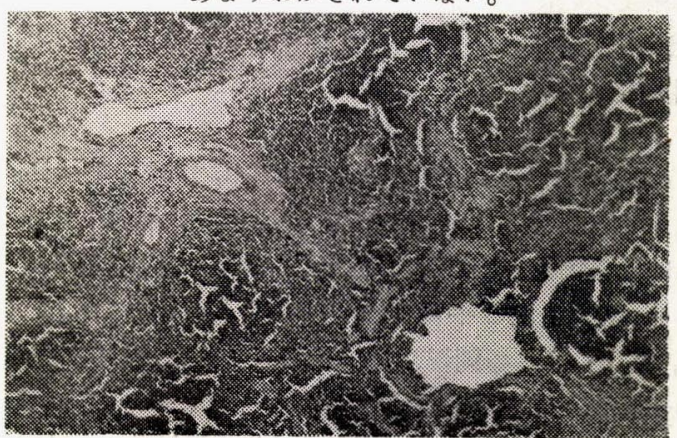

$5 \mathrm{mg} / \mathrm{kg} /$ day 21 日間注射後屠殺の脾䐟 滤胞は比輍的残存して萎縮像著明。

\section{近交系実験動物における量的形質の不均一性につレて}

\section{永 井 次 郎 東京大学農学部家畜育種学教室}

生物学的㭘定のときのよ5に一定刺戟に対して均一な 反応を得たいときには，一般に数十代に亘つて兄妹交配 を続けてきた近交系ラット，マウスをこれまで用いてき た。近交系動物は, 或る形質例えば発がん率等に関して は系統特有の発生率を示し, 系統内の家系間には顕著な 変異がみられない上5である。ところが,或る形質例えば 一定日令に打ける体重, 一定量の薬物投与に対する反応 等のような量的形質に関しては, 家系間, 個体間にかな り差がみられ，必らずしも均一性を期し難いという事が 最近報告されている。そこでここに近交系動物に拈ける
量的形質の不均一性の問題をとりあけ゚検討してみた。

一般に形質は，発病しているか，していないかという ような質的形質或いは不運続的形質と体重のような量的 形質或いは連続的形質とに大別することが出来る。（質 的形質も，とらえよ5によつては量的形質とみなすこと が出来, 連続的形質として扱うことが出来る場合があ る。例えば犬の鳴き声を高い，低いとい５度合でなく， 音波としてとらえた場合など。）量的形質は遺伝的要因 並びに環境的要因によつて影響をうけ，一般に複雑な生 理機構を通じて発現する形質が多い。例えば孚腺の発育 